\title{
Astronomy and its role in ancient Mesoamerica
}

\author{
Ivan Šprajc \\ Scientific Research Center of the Slovenian Academy of Sciences and Arts, \\ Novi trg 2, 1000 Ljubljana, Slovenia \\ email: sprajc@zrc-sazu.si
}

\begin{abstract}
The observation of the sky had an important rôle among the Maya, Aztecs and other prehispanic peoples of Mesoamerica. Their familiarity with the regularities of the apparent motion of the Sun, the Moon and bright planets is attested in a large amount of astronomical data contained in codices and monumental hieroglyphic inscriptions, as well as in their sophisticated calendrical system. On the other hand, the study of architectural alignments has disclosed that civic and ceremonial buildings were largely oriented on astronomical grounds, mostly to sunrises and sunsets on certain dates, allowing the use of observational calendars that facilitated a proper scheduling of agricultural and the associated ritual activities in the yearly cycle. Both accurate knowledge and other astronomically-derived concepts reveal that the significance attributed to certain celestial events by the ancient Mesoamericans can be explained in terms of the relationship of these phenomena with specific environmental and cultural facts, such as seasonal climatic changes and subsistence strategies. It was particularly due to its practical utility that astronomy, intertwined with religious ideas and practices, had such an important place in the worldview and, consequently, in the cosmologically substantiated political ideology of Mesoamerican societies
\end{abstract}

Keywords. Mesoamerica, Maya, Aztec, archaeoastronomy

\section{Introduction}

Mesoamerica is a culturally defined geographical area corresponding to central and southern parts of modern Mexico and northern part of Central America. The term refers to the territory on which civilisations with a number of common cultural traits flourished since the 2nd millennium BCE, when the first complex, state-organized societies emerged, until the Spanish conquest in the early 16th century. The history of Mesoamerica is traditionally divided into three main periods or evolutionary stages: the Preclassic (ca. 2000 BCE - 250), Classic (250 - 900) and Postclassic (900 - 1519). The earliest stratified and urban societies appeared during the Preclassic along the southern part of the Mexican Gulf Coast, in central Mexico and in the Maya area in the Mesoamerican southeast. The greatest splendor, particularly notable in fine arts, architectural achievements and writing systems, was reached during the Classic period, whereas the Postclassic was characterised by intensified migrations, pronounced militarisation and, particularly in the Maya area, by increased political fragmentation.

The antiquity of astronomy and its importance attested in all ancient civilizations (van der Waerden 1974; White 1959) can be accounted for by its practical uses. The celestial poles and directions in which the objects in the sky rise and set provide basic references for the orientation in space, whereas the cyclical motions of celestial bodies allow orientation in time. The problem of the measurement of time has been defined as "peculiarly one of astronomy" (Woolard \& Clemence 1966); moreover, various cyclical changes 
observable in the sky coincide with seasonal changes in natural environment, but since the periodicity of celestial events is much more stable and exact, the observation of these regularities allowed ancient societies to predict annual changes in their environments and to regulate their activities in time. Therefore, the need for astronomical observations increased notably with the origin of agriculture. Since this form of subsistence requires an orderly scheduling of labors in the yearly cycle, astronomical knowledge offered adaptive advantages to the societies possessing better specialists in this field and, consequently, acquired great importance in early states: making subsistence strategies more efficient, it contributed to the legitimation of power of the ruling class (Reyman 1975; Broda 1982; Aveni \& Hartung 1986; Iwaniszewski 1989; Šprajc 1996).

Astronomical observations resulted, on the one hand, in a corpus of exact and practically useful knowledge. On the other hand, since the celestial order, apparently invariable and perfect, came to be considered superior to the terrestrial and human order, this notion gave rise to an enormous variety of myths explaining the universe in terms of cause and effect, and beliefs according to which the events on the Earth depend on the phenomena observed in the sky. In any particular social group, the exact concepts and those defined in terms of our current knowledge as "non-scientific" are normally intertwined and integrated in a relatively coherent worldview, which can be properly understood only if examined as a whole and in the light of the specific natural, social and historical context; both correct and false ideas may thus shed light on a number of aspects of the society being studied. This holistic approach, considering not only the exact knowledge about celestial phenomena but rather all astronomically-derived concepts and related cultural manifestations, has been adopted by archaeoastronomy, a relatively new anthropological discipline whose interest is focused on cultural transformation of astronomical facts. Taking into account specific environmental peculiarities, subsistence strategies, sociopolitical structure and historical antecedents of the society under study, archaeoastronomy searches responses to a number of questions:

- What were the social functions of astronomical knowledge?

- Why did certain astronomical phenomena acquire a prevailing importance?

- Which were the observational bases of the concepts embedded in myths, iconography, attributes of gods, etc.?

- What is the nature of interrelationship between astronomical concepts, natural environment and cultural context?

In its attempts to solve this kind of problems, archaeoastronomy participates in common efforts of anthropological disciplines and contributes to a more comprehensive understanding of ancient societies, as well as of general processes of cultural evolution (Aveni 1989, 2001, 2003; Broda 1982, 1992; Iwaniszewski 1989, 1994; Ruggles 1999; Šprajc 2005).

Mesoamerican archaeoastronomy relies on a large variety of sources. The images and hieroglyphic texts in prehispanic manuscripts or codices, monumental inscriptions, mural paintings, reliefs and other archaeological objects provide highly interesting data on astronomical concepts and practices. Complementary information is contained in early colonial documents and, considering that fragments of prehispanic cultural heritage survive in modern indigenous communities, even in the ethnographic material. Furthermore, relevant data on prehispanic astronomy are embedded in spatial distribution of archaeological vestiges, particularly in architectural orientations and other alignments detected in ancient cultural landscapes. 


\section{Astronomy in codices, monumental inscriptions and post-conquest written sources}

Like any other precise calendar invented in the history of humankind, the complex Mesoamerican calendrical system (Aveni 2001; Kelley 1976; Lounsbury 1978; Thompson 1950) had astronomical bases. The relation between the tropical year and the 365-day Mesoamerican calendrical year is evident. While the origin of the other pan-Mesoamerican calendrical cycle composed of 260 days is less clear, it has been noticed that the length of two 260-day periods corresponds, with reasonable accuracy, to three eclipse half-years of 173.31 days, and that the synodic period of Mars (779.94 days) equals almost exactly three 260-day cycles. It has also been suggested that the 260-day count was invented somewhere along the 15th parallel North, because at this latitude the passages of the Sun through the zenith are separated by intervals of 105 and 260 days (Aveni 2001; Malmström 1997; Šprajc 2001a). Whatever its origin, this cycle, unique in the history of humankind, had an enormous importance in all calendrical and astronomical computations.

The Sun had, obviously, a prominent rôle in the Mesoamerican world view, and the 365-day calendrical year, composed of 18 months of 20 days and an additional 5-day period, was likely derived from the observation of the Sun's annual movement along the horizon. This is suggested by the importance of solstitial extremes, attested since early periods and reflected not only in architectural orientations (see below) but also in the concept, apparently pan-Mesoamerican, that the corners and bearers of the sky are located at the four solstitial points on the horizon (cf. Milbrath 1999; Šprajc 2001a). The zenith passages of the Sun were also observed, particularly important being the first annual transit; even if its exact date depends on the latitude, this event occurs throughout Mesoamerica in late April or May and thus announces, or coincides with, the onset of the rainy season, a crucial moment in the agricultural cycle (Aveni 2001; Tedlock 1992; Šprajc 2001a).

Although the Mesoamerican calendar exhibits no direct relationship with the Moon, it is possible that the 20-day months composing the calendrical year replaced earlier lunar months (Caso 1967; Lounsbury 1978; Stewart 1984). In any case, the Moon had an important rôle in the Mesoamerican world view (Milbrath 1999; Thompson 1939; Galindo Trejo 1994). Chronological information in Maya hieroglyphic inscriptions regularly includes the data on the "age" of the Moon, expressed in a relatively complex way in the so-called Lunar Series. Since they used no fractional numbers, the Maya assigned to a lunar month the length of 29 or 30 days; to keep their lunar months in step with lunations of 29.53059 days during longer periods, they alternated their 29- and 30-day months using different formulae, which allowed them to achieve a remarkable degree of precision reflected in lunar data calculated for dates in distant past and future (Lounsbury 1978; Aveni 2001; Cases et al. 2004; Fuls 2007).

In all ancient traditions, the eclipses were considered as bad auguries, obviously because, being relatively rare and difficult to predict, apparently bring disorder into the cosmic harmony. In various prehispanic codices and early colonial sources we find records of eclipses that occurred in decades before and after the Spanish Conquest, as well as information on native beliefs concerning these phenomena, and on ritual performances intended to prevent their negative influences (Lehmann 1968; Caso 1967; Aveni 2001; Galindo Trejo 1994). The ideas surrounding the eclipses were, however, not limited to fear or anxiety; we know that the Mesoamerican astronomers-priests achieved a rather sophisticated knowledge about the periodicity of eclipses. While some data of this kind are contained in monumental inscriptions (Lounsbury 1978; Justeson 1989), the most 
explicit information can be found in the Dresden Codex, one of the few Maya manuscripts that survived to our time. The intervals of 177 and 148 days connecting the dates listed on pages 51 to 58, which constitute the so-called Lunar Table, indicate that the Maya were aware of the occurrence of eclipses at regular intervals. The purpose of such tables was an astrological one: if the possibility or "danger" of an eclipse could be predicted, the appropriate ritual acts could be performed on time (Thompson 1972; Lounsbury 1978; Aveni 2001; Bricker \& Bricker 1983; Justeson 1989; ; Knowlton 2003).

The complex knowledge possessed by the priestly elite in prehispanic times was lost soon after the Conquest, mostly as a result of Christian indoctrination imposed by Spanish clergy. However, modern indigenous groups, for which the Moon continues to have a great importance, keep observing its motion. Particular attention is paid to its phases believed to determine appropriate moments for accomplishing diverse activities, especially those in the agricultural cycle (Köhler 1991a; Tedlock 1992; Lupo 1991).

Among the planets observed in Mesoamerica, the most important one was Venus. The finest example of the knowledge on this planet is found in the Dresden Codex. Pages 46 to 50 of this manuscript compose a Venus table, each page referring to one synodic period of 584 days. The table is composed of five pages, reflecting the commensurability of five synodic periods and eight calendrical years, while the complete run of the table embraces 37,960 days or 104 years, which is the lowest common multiple of the canonical Venus period of 584 days and of the 260-day count $(37,960=65 \times 584=146 \times 260=104 \times$ $365)$. Even if the difference between the true mean length of Venus synodic revolution (583.92 days) and the canonical value assigned to this period by the Mesoamericans (584 days) resulted in an error of 5.2 days accumulated after the complete run of the table, the introductory information on page 24 of the codex suggests that the table was "recyclable" and that, occasionally, correction mechanisms were applied, with the purpose of maintaining the dates of particular Venus phenomena predicted by the table (first and last appearances of the morning and evening star) in accordance with observational reality (Thompson 1972; Lounsbury 1978, 1983; Aveni 1992, 2001; Šprajc 1996).

Multiple aspects of the significance of Venus in the Mesoamerican world view are documented in hieroglyphic texts, in imagery on ceramic vessels, codices and sculpted monuments, and in myths recorded in early colonial writings. While the morning star at its first appearance after inferior conjunction was believed to inflict harm on nature and humankind (Thompson 1972; Aveni 2001), the planet also had an important place in beliefs about rain, maize and fertility. It has been found out that the maximum and minimum declinations of Venus, observable as northernmost and southernmost rising and setting points of the planet, maintain a constant seasonal relationship, and that the evening star extremes, falling in April-May and October-November, coincide with the beginning and the end of the rainy season and, therefore, also delimit the agricultural cycle in Mesoamerica; furthermore, there is evidence suggesting that these phenomena were the main observational motive of the amply documented Venus-rain-maize conceptual association, in which the evening aspect of the planet, indeed, had a prevalent rôle. On the other hand, Venus figured prominently in ideas and ritual practices linked to warfare and sacrifice, and was also believed to be an eclipse agent (Carlson 1991; Closs 1994; Milbrath 1999; Šprajc 1993a,b, 1996).

While other planets seem to have had much less importance, pages 43 to 45 of the Dresden Codex have been interpreted as a Mars table (Bricker \& Bricker 1986; Aveni 2001; Love 1995), and references to Jupiter and Saturn have been found in some Maya texts (Fox \& Justeson 1978; Lounsbury 1989; Aveni \& Hotaling 1994).

A number of prehispanic constellations or asterisms have been identified (Aveni 2001; Galindo Trejo 1994; Köhler 1991b; Lupo 1991; Tedlock 1992; Justeson 1989; Milbrath 
1999). The most interesting data concerning Maya constellations are contained in the prehispanic manuscript known as the Paris Codex. The images on pages 23 and 24, mostly representing animals hanging from celestial bands and accompanied by dates, have been interpreted by various researchers as a Maya zodiac, even if there is no agreement about the functioning of the table and the identity of constellations represented by different images (Kelley 1976; Aveni 2001; Justeson 1989; Bricker \& Bricker 1992; Love 1994).

\section{Astronomical properties of mesoamerican architecture}

Fray Toribio de Motolinía (1971), a Spanish friar who arrived to Mexico soon after the Conquest, writes in his main work Memoriales that the Aztec calendrical feast of Tlacaxipehualiztli "took place when the Sun stood in the middle of [the Temple of] Huitzilopochtli, which was at the equinox, and because it was a little out of line, [King] Moctezuma wished to pull it down and set it right" (Aveni 2001). The complementary information can be found in a map of Tenochtitlan attributed to Cortés, where the face of the Sun is shown between the twin sanctuaries of the Templo Mayor (Aveni 2001; Šprajc 2000). Even if, aside from some drawings in prehispanic and Conquest-period codices, these seem to be the only documentary sources alluding to the astronomical orientation of a prehispanic temple, it can now be affirmed that the practice of orienting ceremonial buildings on astronomical grounds was common in Mesoamerica.

Systematic research carried out during the last few decades has revealed that Mesoamerican architectural orientations exhibit a clearly non-uniform distribution and that civic and ceremonial buildings were largely oriented on the basis of astronomical considerations, particularly to the Sun's positions on the horizon on certain dates of the tropical year (Aveni 2001, 2003; Aveni, Dowd \& Vining 2003; Aveni \& Hartung 1986, 2000; Galindo Trejo 1994; Tichy 1991; Šprajc 2000, 2001b, 2008). The earliest orientations in Mesoamerica refer to solstitial sunrises and sunsets, probably because the solstices, marked by easily perceptible extremes of the Sun's movement along the horizon, must have been the most elementary references for orientation in time. Other two rather easily determinable dates are the so-called quarter-days of the year, or mid-points in time between the solstices (March 23 and September 21, \pm 1 day). While there is no compelling evidence that the true equinoxes were known in Mesoamerica, the orientations to sunsets on the quarter-days of the year are quite common (Aveni 2001; Aveni, Dowd \& Vining 2003; Aveni \& Hartung 1986, 2000; Tichy 1991; Šprajc 2001b, 1995, 2008). The solstitial and quarter-day orientations are not limited to the early periods of Mesoamerica; in later times, however, more complicated orientation principles began to prevail.

Recent studies based on a number of archaeological sites with monumental architecture in central Mexico and in the Maya area have revealed that many alignments allowed the use of observational calendars composed of calendrically significant and, therefore, easily manageable intervals: the intervals separating the sunrise and sunset dates recorded by orientations at a particular site tend to be multiples of 13 or 20 days, i.e. basic periods of the Mesoamerican calendrical system. The correspondence between the most frequently recorded dates and the crucial moments of the cultivation cycle suggests that the observational schemes, reconstructed for a number of sites, served for predicting important seasonal changes and for an efficient scheduling of the corresponding agricultural and associated ritual activities (Aveni \& Hartung 1986; Aveni, Dowd \& Vining 2003; Aveni \& Hartung 1986; Šprajc 2000, 2001b, 2008). It should be recalled that, since the Mesoamerican calendrical year of 365 days, due to the lack of intercalations, did not maintain a perpetual concordance with the tropical year of 365.2422 days, astronomical observations were always necessary. The orientations, marking critical and canonized moments of the 
year of the seasons, not only allowed their determination by means of direct observations; if the observational schemes were composed of elementary periods of the formal calendrical system, it was relatively easy to anticipate the relevant dates (which was important because cloudy weather may have impeded direct observations on these dates), knowing the structure of a particular observational calendar and the mechanics of the formal one. Particularly important for these purposes must have been the 260-day calendrical count, in which the cycles of 13 and 20 days were intermeshing, so that every date had a name composed of a number from 1 to 13 and a sign in the series of 20. Given the structure of this calendrical count, the sunrises and sunsets separated by 13-day intervals and their multiples occurred on the dates with the same numeral, while the events separated by periods of 20 days and their multiples fell on the dates having the same sign (Šprajc 2001b).

In some cases, the relevant dates were marked by interesting light-and-shadow effects produced by appropriate spatial arrangement of certain architectural elements (Anderson, Morales \& Morales 1981; Aveni 2001; Aveni, Milbrath \& Peraza Lope 2004; Carlson 1999; Galindo Trejo 1994; Šprajc 1995). For central Mexico it has been shown, furthermore, that the dates composing observational calendars were recorded not only by architectural orientations but also by prominent peaks on the local horizon, which means that the most important buildings were not only oriented but also located on astronomical grounds, with the purpose of using the surrounding hilltops as markers of sunrises and sunsets on the most relevant dates (Šprajc 2001b).

While the orientations in Mesoamerican architecture are predominantly solar, a few alignments to Venus extremes have also been identified. In the light of available data, and considering that the extremes of Venus visible on the eastern and western horizon have been found to be asymmetrical, it can be ascertained that all Venus orientations known so far refer to the evening star extremes, whose significance is attributable to the fact that they approximately delimit the rainy season (Aveni, Gibbs \& Hartung 1975; Šprajc 1993a, 1996). Some architectural alignments may also refer to the rising or setting points of brilliant stars (Aveni 2001).

\section{Concluding remarks}

Mesoamerican astronomy had a complex social rôle. According to a number of sources, the most sophisticated astronomical knowledge was possessed by the priestly class closely associated with the ruling élite. Both early colonial documents and Maya hieroglyphic texts suggest that the Mesoamerican rulers were deeply concerned with what was occurring in the sky (Aveni 2001).

Astronomical interests of those holding political power come as no surprise. In both Mesoamerican and other ancient civilisations, whose subsistence was based on intensive agriculture, the ability to predict important seasonal changes in natural environment was of paramount importance; in the absence of a calendar accurately reproducing seasonal cycles, however, reliable predictions could only be based on astronomical observations performed by specialists familiar with cyclical celestial phenomena and their concomitance with annual climatic variations. Considering that a more efficient distribution of activities in the agricultural cycle increased productivity and secured survival to a larger population, the astronomers-priests' professional skills must have been vital for successful economy and a smooth functioning of the existing social and political system.

In view of the parallelism observed between the movement of celestial bodies and the alternation of seasonal changes in natural environment, and because the intervals at which astronomical phenomena recur are much more constant and precise than those 
separating other cyclical events observable in the nature, the sky was considered, since time immemorial, to be the image of divine perfection and supreme order to which human and earthly order was subordinated. With the origin and development of social stratification, such beliefs were modified and incorporated into the ideology that was elaborated, declared and imposed by the ruling élite, with the purpose of sanctioning and maintaining the existent social order. The rulers were believed to be men-gods responsible for performing ritual activities that guaranteed a proper development of natural cycles and the preservation of the ideal cosmic order (cf. López Austin 1973). Advances in astronomical knowledge made the achievement of these objectives more effective, as they allowed the most appropriate moments for every ceremonial act to be determined with greater precision. Moreover, reliable predictions of celestial events and the corresponding astrological auguries contributed to the legitimation of power, justifying the privileges enjoyed by the rulers and their collaborators dedicated to priesthood, astronomy and calendar (Aveni 1989, 2001, 2003; Broda 1982, 1992; Šprajc 1996, 2005).

The apparently immutable and perfect order observed in the sky, obviously superior to the one reigning on the earth, must have been the primary source of deification of heavenly bodies, whose cyclic behavior thus was not viewed as being simply correlated with seasonal transformations in natural environment but rather as provoking them. Assuming, therefore, that the proper annual movement of the Sun, Venus and other celestial bodies was believed to be responsible for timely occurrences of these changes, the directions to the points of their rising and setting on crucial dates of the yearly cycle must have acquired a sacred dimension. Consequently, the alignments reproducing significant astronomical directions in civic and ceremonial architecture can be interpreted not only as a sanctified materialization of the union of space and time, whose importance in the Mesoamerican world view is attested in different sources, but also as a manifestation of the attempts of the governing class to legitimate its power by recreating and perpetuating the cosmic order in the earthly environment. The astronomical alignments, just like other types of evidence, clearly show that Mesoamerican astronomy, including its practical use, was embedded in the ritual and intimately related to social organization, religion and political ideology of prehispanic societies.

\section{References}

Anderson, N. S., Morales, M. \& Morales, A. 1981, Archaeoastronomy: The Bulletin of the Center for Archaeoastronomy, 4, 34

Aveni, A. F. 1989, in World Archaeoastronomy, A. F. Aveni (ed) (Cambridge: Cambridge University Press), p. 3

Aveni, A. F. 1992, in The Sky in Mayan Literature, A. F. Aveni (ed) (Oxford: Oxford University Press), p. 87

Aveni, A. F. 2001, Skywatchers: A Revised and Updated Version of Skywatchers of Ancient Mexico (Austin: University of Texas Press)

Aveni, A. F. 2003, Journal of Archaeological Research, 11, 149

Aveni, A. F., Dowd, A. S. \& Vining, B. 2003, Latin American Antiquity, 14, 159

Aveni, A. F., Gibbs, S. L. \& Hartung, H. 1975, Science, 188, 977

Aveni, A. F. \& Hartung, H. 1986, Maya City Planning and the Calendar, Transactions of the American Philosophical Society, Vol. 76, part 7

Aveni, A. F. \& Hartung, H. 2000, in In chalchihuitl in quetzalli: Mesoamerican studies in honor of Doris Heyden E. Quiñones Keber (ed) (Lancaster: Labyrinthos), p. 55

Aveni, A. F. \& Hotaling, L. D. 1994, Archaeoastronomy, 19, S21

Aveni, A. F., Milbrath, S. \& Peraza Lope, C. 2004, Res: Journal of Anthropology and Aesthetics, 45,123

Bricker, H. M. \& Bricker, V. R. 1983, Current Anthropology 24, 1 
Bricker, H. M. \& Bricker, V. R. 1992, in The Sky in Mayan Literature, A. F. Aveni (ed) (Oxford: Oxford University Press), p. 148

Bricker, V. R. \& Bricker, H. M. 1986, in Research and Reflections in Archaeology and History: Essays in Honor of Doris Stone, E. W. Andrews V (ed) (New Orleans: Tulane University), p. 51

Broda, J. 1982, in Ethnoastronomy and Archaeoastronomy in the American Tropics A. F. Aveni \& G. Urton (eds), Annals of the New York Academy of Sciences, 385), 81

Broda, J. 1986, in Historia de la astronomía en México, M. A. Moreno Corral (ed) (México: Fondo de Cultura Económica), p. 65

Broda, J. 1992, Cuadernos de Arquitectura Mesoamericana, 19, 23

Carlson, J. B. 1991, Venus-regulated Warfare and Ritual Sacrifice in Mesoamerica: Teotihuacan and the Cacaxtla "Star Wars" Connection (College Park: Center for Archaeoastronomy)

Carlson, J. B. 1999, Archaeoastronomy: The Journal of Astronomy in Culture, 14, 136

Cases, J. I., Belmonte, J. A. \& Lacadena, A. 2004, in Etno y arqueo-astronomía en las Américas M. Boccas, J. Broda \& G. Pereira (eds), Memorias del Simposio ARQ-13 del 51 Congreso Internacional de Americanistas (Santiago de Chile: ICA 51), p. 195

Caso, A. 1967, Los calendarios prehispánicos (México: Universidad Nacional Autónoma de México)

Closs, M. P. 1994, in Seventh Palenque Round Table, 1989, V. M. Fields (ed) (San Francisco: The Pre-Columbian Art Research Institute), p. 229

Fox, J. A. \& Justeson, J. S. 1978, Contributions of the University of California Archaeological Research Facility, 36, 55

Fuls, A. 2007, Ancient Mesoamerica, 18, 273

Galindo Trejo, J. 1994, Arqueoastronomía en la América antigua (México: CONACYT; Madrid: Ediciones Equipo Sirius)

Iwaniszewski, S. 1989, in World Archaeoastronomy, A. F. Aveni (ed), (Cambridge: Cambridge University Press), p. 27

Iwaniszewski, S. 1994, Trabajos de Prehistoria, 51, 5

Justeson, J. S. 1989, in World Archaeoastronomy, A. F. Aveni (ed), (Cambridge: Cambridge University Press), p. 76

Kelley, D. H. 1976, Deciphering the Maya Script (Austin: University of Texas Press)

Knowlton, T. 2003, Journal for the History of Astronomy, 34, 291

Köhler, U. 1991a, in Arqueoastronomía y etnoastronomía en Mesoamérica, J. Broda, S. Iwaniszewski \& L. Maupomé (eds) (México: Universidad Nacional Autónoma de México), p. 235

Köhler, U. 1991b, in Arqueoastronomía y etnoastronomía en Mesoamérica, J. Broda, S. Iwaniszewski \& L. Maupomé (eds) (M'exico: Universidad Nacional Autónoma de México), p. 249

Lehmann, W. 1968, Traducciones Mesoamericanistas, 2, 31

López Austin, A. 1973, Hombre-dios: Religión y política en el mundo náhuatl (México: Universidad Nacional Autónoma de México)

Lounsbury, F. G. 1978, in Dictionary of Scientific Biography, C. Gillispie (ed) (New York: Charles Scribner's Sons), Vol. 15, suppl. I, 759

Lounsbury, F. G. 1983, in Calendars in Mesoamerica and Peru: Native American Computations of Time, A. F. Aveni \& G. Brotherston (eds) (Oxford: BAR International Series 174), p. 1

Lounsbury, F. G. 1989, in World Archaeoastronomy, A. F. Aveni (ed) (Cambridge: Cambridge University Press), p. 246

Love, B. 1994, The Paris Codex: Handbook for a Maya Priest (Austin: University of Texas Press)

Love, B. 1995, Latin American Antiquity, 6, 350

Lupo, A. 1991, in Arqueoastronomía y etnoastronomía en Mesoamérica, J. Broda, S. Iwaniszewski \& L. Maupomé (eds) (México: Universidad Nacional Autónoma de México), p. 219

Malmström, V. H. 1997, Cycles of the Sun, Mysteries of the Moon: The Calendar in Mesoamerican Civilization (Austin: University of Texas Press)

Martin, F. 1993, Latin American Antiquity, 4, 74

Milbrath, S. 1999, Star gods of the Maya (Austin: University of Texas Press) 
Motolinía, T. 1971, Memoriales o libro de las cosas de la Nueva España y de los naturales de ella (México: Universidad Nacional Autónoma de México)

Reyman, J. E. 1975, in Archaeoastronomy in Pre-Columbian America, A. F. Aveni (ed) (Austin: University of Texas Press), p. 205

Ruggles, C. 1999, Astronomy in Prehistoric Britain and Ireland (New Haven : Yale University Press)

Stewart, J. D. 1984, Estudios de Cultura Náhuatl, 17, 171

Šprajc, I. 1993a, Journal for the History of Astronomy, 24, 17

Šprajc, I. 1993b, Archaeoastronomy, 18, S27

Šprajc, I. 1995, in Memorias del Segundo Congreso Internacional de Mayistas (México: Universidad Nacional Autónoma de México), p. 585

Šprajc, I. 1996, La estrella de Quetzalcóatl: El planeta Venus en Mesoamérica (México: Diana)

Šprajc, I. 2000, Archaeoastronomy, 25, S11

Šprajc, I. 2001a, in Historia antigua de México, L. Manzanilla \& L. López Luján (eds) (México: Instituto Nacional de Antropología e Historia , Universidad Nacional Autónoma de México \& M. A. Porrúa), Vol. 4, pp. 273

Šprajc, I. 2001b, Orientaciones astronómicas en la arquitectura prehispánica del centro de México (México: Instituto Nacional de Antropología e Historia)

Šprajc, I. 2005, Latin American Antiquity, 16, 209

Šprajc, I. 2008, in Reconocimiento arqueológico en el sureste del estado de Campeche, México: 1996-2005, I. Šprajc (ed) (Oxford: BAR International Series 1742), p. 233

Tedlock, B. 1992, in The Sky in Mayan Literature, A. F. Aveni (ed) (Oxford: Oxford University Press), pp. 18

Thompson, J. E. S. 1939, Contributions to American Anthropology and History, Publ. 509 (Washington: Carnegie Institution of Washington)

Thompson, J. E. S. 1950, Maya Hieroglyphic Writing: An Introduction, Publ. 589 (Washington: Carnegie Institution of Washington)

Thompson, J. E. S. 1972, A Commentary on the Dresden Codex: A Maya Hieroglyphic Book (Philadelphia: Memoirs of the American Philosophical Society, 93)

Tichy, F. 1991, Die geordnete Welt indianischer Völker: Ein Beispiel von Raumordnung und Zeitordnung im vorkolumbischen Mexiko (Stuttgart: F. Steiner)

Waerden, B. L. van der 1974, Science Awakening II: The Birth of Astronomy (Leyden: Noordhoff International; Oxford: Oxford University Press)

White, L. A. 1959, The Evolution of Culture: The Development of Civilization to the Fall of Rome (New York: McGraw-Hill)

Woolard, E. W. \& Clemence, G. M. 1966, Spherical Astronomy (New York: Academic Press) 